\title{
PROPOSED METHODOLOGY OF VULNERABILITY AND CONTAMINATION RISK MAPPING FOR THE PROTECTION OF KARST AQUIFERS IN SLOVENIA
}

\author{
PREDLOG METODOLOGIJE KARTIRANJA RANLJIVOSTI IN \\ TVEGANJA ZA ONESNAŽENJE VODA ZA VAROVANJE KRAŠKIH \\ VODONOSNIKOV V SLOVENIJI
}

\author{
Nataša RAVBAR ${ }^{1} \&$ Nico GOLDSCHEIDER ${ }^{2}$
}

\begin{abstract}
UDC 551.44:556.388(497.4)

Nataša Ravbar \& Nico Goldscheider: Proposed methodology of vulnerability and contamination risk mapping for the protection of karst aquifers in Slovenia

On the basis of work accomplished by the European COST Action 620, a comprehensive approach to groundwater vulnerability and contamination risk assessment is proposed, taking into account the special characteristics of Slovene karst aquifer systems. The Slovene Approach is consistent with national environmental legislation and enables comparison across European countries. The method integrates temporal hydrological variability in the concept of groundwater vulnerability and offers a new possibility to combine surface and groundwater source and resource protection, which required the development of a new $\mathrm{K}$ factor (karst groundwater flow within the saturated zone). The risk analysis considers intrinsic vulnerability, contamination hazards and the importance of the source or resource. It has been first applied to the Podstenjšek springs catchment in southwestern Slovenia and validated by means of two multi-tracer tests with a total of six injection points. The resulting vulnerability, hazard and risk maps are plausible, and the validation confirmed the vulnerability assessment at the representative sites that were selected for tracer injection. The maps provide improved source protection zones and make it possible to identify land mismanagement and to propose better practices for future planning.

Keywords: Slovene Approach, groundwater vulnerability, contamination risk, karst aquifer, water source protection and management, validation of vulnerability maps.
\end{abstract}

Izvleček UDK 551.44:556.388(497.4) Nataša Ravbar \& Nico Goldscheider: Predlog metodologije kartiranja ranljivosti in tveganja za onesnaženje voda za varovanje kraških vodonosnikov $v$ Sloveniji

Upoštevajoč posebnosti slovenskega krasa smo na podlagi smernic evropskega projekta COST Action 620 predlagali splošen pristop $\mathrm{k}$ ocenjevanju ranljivosti in tveganja kraških voda za onesnaženje. Tako imenovani Slovenski pristop ustreza slovenski okoljski zakonodaji in omogoča primerjavo $\mathrm{z}$ razmerami v Evropi. Metoda pri ocenjevanju ranljivosti podtalnice upošteva časovno hidrološko spremenljivost, ponuja možnost povezovanja zaščite površinskih in podzemnih voda ter predlaga nove smernice za zaščito podzemne vode in vodnih virov, za kar je bil razvit nov faktor $\mathrm{K}$ (pretakanje kraških voda $\mathrm{v}$ zasičeni coni). Slovenski pristop predvideva obširno analizo tveganja, ki temelji na oceni naravne ranljivosti, dejanskih in potencialnih obremenjevalcev ter pomembnosti vodnega vira oziroma podzemne vode. Predlagana metodologija je bila prvič uporabljena v zaledju vodnega vira Podstenjšek v jugozahodni Sloveniji, rezultati pa preverjeni s pomočjo dveh sledilnih poizkusov, ki sta skupno zajemala šest injicirnih točk. Rezultati kart naravne ranljivosti, obremenjevalcev in tveganja so zadovoljivi. Preverjanje potrjuje ocenjeno naravno ranljivost reprezentativnih točk, izbranih za injiciranje sledila. Končne karte omogočajo izpopolnjeno razmejitev vodovarstvenih pasov ter označujejo območja neustreznega ravnanja, nudijo podlago za reorganizacijo dejavnosti in za boljše rešitve $\mathrm{v}$ prihodnjem načrtovanju.

Ključne besede: Slovenski pristop, ranljivost podzemne vode, tveganje za onesnaženje, kraški vodonosnik, zaščita in upravljanje $\mathrm{z}$ vodnimi viri, preverjanje kart ranljivosti.

\footnotetext{
${ }^{1}$ Karst Research Institute SRC SASA, Titov trg 2, SI-6230 Postojna, Slovenia, e-mail: natasa.ravbar@zrc-sazu.si

${ }^{2}$ Centre of Hydrogeology, University of Neuchâtel, 2009 Neuchâtel, Switzerland, e-mail: nico.goldscheider@unine.ch

Received/Prejeto: 14.09.2007
} 


\section{INTRODUCTION}

Karst springs are the most important drinking water sources in Slovenia, because of their good quality and sufficient amount. Unfortunately, in the Slovene legislation on water sources protection, the special characteristics of karst aquifers are insufficiently taken into consideration (Ravbar \& Kovačič 2006). Although the quality of karst waters is relatively high, individual examples of contamination illustrate the shortcomings of water management even in uninhabited alpine karst areas, which are ordinarily very favourable for protection.

In some other countries, groundwater vulnerability and risk maps are used for protection zoning and land use planning in karst. Thus, different methods have already been developed and implemented in numerous test sites worldwide. Moreover, in some European countries, vulnerability mapping has been integrated in the state protection legislation. However, in Slovenia experiences of such applications are very modest - only two karst spring vulnerability studies have been done so far (Janža \& Prestor 2002; Petrič \& Šebela 2004).

In order to provide comparable guidelines for the protection of carbonate aquifers in individual regions of Europe, COST Action 620 developed a general conceptual framework for vulnerability and risk mapping (Daly et al. 2002; Zwahlen 2004). There are two types of vulnerability: the intrinsic vulnerability only depends on the hydrogeological characteristics of an area determining its protective function against contamination; the specific vulnerability additionally considers the properties of specific contaminants. Vulnerability and risk maps can be prepared for a groundwater resource or for a specific source, such as a tapped spring or a pumping well.
On this basis, a comprehensive approach for groundwater vulnerability and contamination risk assessment is proposed as an alternative to the existing karst groundwater management in Slovenia. The Slovene Approach includes three elements: the intrinsic vulnerability map, the hazard map and the contamination risk map. The methodology takes into account special characteristics of Slovene karst aquifer systems; it is consistent with national environmental legislation and enables comparison across European countries.

The Slovene Approach offers a new possibility to integrate surface and groundwater protection. In addition, it includes two new aspects for the intrinsic vulnerability mapping, which have not yet been sufficiently addressed in the previous methods. Temporal hydrologic variability is particularly important for contaminant transport (Ravbar \& Goldscheider 2006; Göppert \& Goldscheider 2007) and has thus been integrated in the concept of groundwater vulnerability assessment. Furthermore, the method considers groundwater flow and transport processes within the saturated zone that are crucial for source protection. The European Approach was completed by including the importance of a water resource or source into the risk analysis. The proposed approach includes relatively detailed assessment schemes and is thus most appropriate for aquifers and spring catchments where extensive data are available or can be obtained, and where small-scale land use planning is considered important. However, for the application in data-poor environments and/or on larger scales, the method can be generalised and adapted to the local conditions.

\section{SLOVENE APPROACH TO GROUNDWATER VULNERABILITY MAPPING}

According to the European Approach, groundwater vulnerability mapping is founded on the assessment of basic factors that control infiltration of water and contaminants from the land surface towards the groundwater, such as Overlying layers $(\mathrm{O})$, Concentration of flow $(\mathrm{C})$ and Precipitation regime $(\mathrm{P})$. There are two general approaches of water protection: resource protection aims to protect the whole groundwater body, while source protection aims to protect a particular spring or well. In the first case, the mostly vertical seepage of water through the unsaturated zone to the uppermost groundwater surface is considered; in the second case, the lateral flow route within the saturated zone should be included as well. Thus an additional factor for the Karst saturated zone (K) has to be considered (Daly et al. 2002).

The Slovene Approach to intrinsic vulnerability assessment is partly based on the Spanish COP method (Vías et al. 2006; Andreo et al. 2006), which represents an integral interpretation of the European Approach. Although the COP method has been successfully applied in different karst areas, it has some weaknesses. Therefore, it has been modified, complemented and extended for source vulnerability mapping. The resource vulnerability map is obtained by combining the $\mathrm{O}, \mathrm{C}$ and $\mathrm{P}$ factors, whereas the source vulnerability map is obtained by su- 


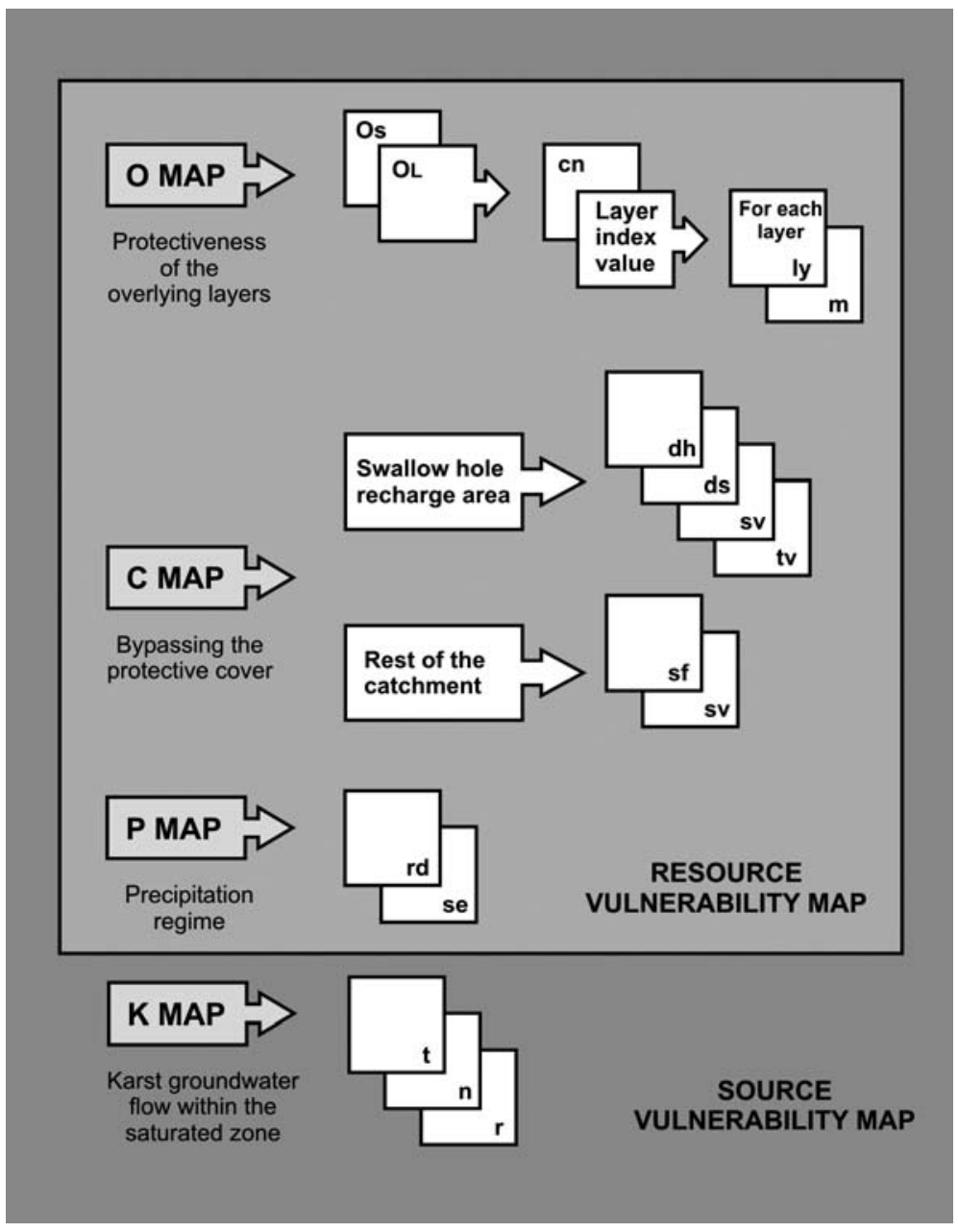

Fig. 1: Principle of the Slovene Approach to groundwater vulnerability mapping.
Furthermore, the protection function of the unsaturated zone is quantified by the lithological characteristics and thickness of each stratum (determining hydrogeological properties, effective porosity and hydraulic conductivity), as well as by the degree of fracturation and/or karstification of the carbonate rocks.

In Slovene karst regions, deep karst plateaux prevail, for which an immediate infiltration of rainwater and fast vertical draining are characteristic. The depth of the unsaturated zone can reach $1500 \mathrm{~m}$ and more. In general, the protective cover of soil and sediments is thin or completely absent. Although great thicknesses of the unsaturated zone may provide some degree of protection, bare karrenfields connected with deep shafts (e.g. the Kaninski Podi, the Kriški Podi, the Rombonski Podi in the Alps and the Ždrocle on the Snežnik mountain) can provoke rapid percolation bypassing the overlying layers. A very low protective value is consequently assigned to such areas.

Confined circumstance of the aquifer is considered as well. In cases where an aquifer under consideration is overlain by another relevant aquifer, the vulnerability of the highest one has to be considered and graphically symbolized on the map, as it is done in the PI method (Goldscheider 2005).

perimposing the resource vulnerability map and the $\mathrm{K}$ factor (Fig. 1).

\section{OVERLYING LAYERS (O FACTOR)}

The $\mathrm{O}$ factor indicates the effectiveness of layers overlying the groundwater surface to protect it against potential contamination (Daly et al. 2002). The $\mathrm{O}$ factor assessment therefore takes into account the residence time of the percolating water (and/or contaminant) through the soil and the rocks composing the unsaturated zone, considerably affected by the thickness, porosity and permeability of each layer.

The evaluation of the soil protection function, where present, is based on its texture (i.e. grain size distribution), soil structure (i.e. the presence of aggregates and macropores) and its thickness. When assessing soil depth (especially of patchy soils) the percolation time through the soil, providing its effective thickness, should be considered.

\section{CONCENTRATION OF FLOW (C FACTOR)}

The $\mathrm{C}$ factor distinguishes areas of different infiltration conditions. It identifies the existence of allogenic point recharges and expresses the degree to which the overlying layers are bypassed. The evaluation of the $\mathrm{C}$ factor is based on the zoning of the swallow hole recharge area, and the rest of the area.

Within the catchment of sinking surface waters, the distance to the swallow hole and the distance to the sinking stream or lake are considered. Most existing methods classify swallow holes, sinking streams and their catchment areas as zones of high or extreme vulnerability. Examples from the Slovene karst show that, due to fast and strong groundwater level oscillations, some swallow holes are frequently or permanently active, while others operate only during exceptional hydrological events, sometimes less than once per year. However, only in case of a permanently active point infiltration, would a contaminant release always and rapidly reach the groundwa- 
ter without significant attenuation, whereas it might not directly enter the karst groundwater in case of an occasionally active one (Ravbar \& Goldscheider 2006). If the swallow holes are not permanently active, the temporal variability sub-factor (tv) should be considered, reducing vulnerability in dependence on the frequency and duration of the swallow hole activity.

Furthermore, sinking streams in Slovenia are sometimes tens of kilometres long and drain catchments of hundreds of $\mathrm{km}^{2}$ (e.g. the Reka river, the Temenica river); there are also examples of large lakes drained by swallow holes (e.g. the lake of Cerkniško Jezero). Regarding the concept of swallow holes and sinking surface waters being extremely vulnerable, this would lead to extremely large areas to be protected at the highest level. We propose to assign a lower degree of vulnerability more than $5 \mathrm{~km}$ upstream from the swallow hole, where surface waters and their catchments should be protected independently from groundwater vulnerability issues, as proposed by existing European and national water protection policies. Areas that drain out of the karst system under consideration, either without contact to the groundwater or via gaining streams, should be assigned a low degree of vulnerability.

In the autogenic recharge area, surface karst landforms (karren, dolines and others) as well as highly fractured areas should be identified, as those represent zones of preferential infiltration and flow concentration (Ford \& Williams 2007). When sediments and soils overly these landforms, the protection is increased.

The infiltration of water is also controlled by slope inclination, vegetation cover and flow type, the last of these having the strongest impact on the vulnerability evaluation. These aspects are considered in the sv subfactor, applicable for both point or diffuse infiltration conditions. The dominant flow process is controlled by the permeability of the layer at or closely below the surface. Where layers are less permeable, surface or shallow subsurface flow often occurs on very flat and even horizontal surfaces. It may eventually infiltrate in more or less concentrated mode, e.g. into a swallow hole. On the other hand, even steep slopes of permeable ground may drain underground and direct infiltration predominates.

Furthermore, the sv sub-factor attributes higher vulnerability to steeper slopes and sparser vegetation. Denser vegetation always provides protection to groundwater due to less runoff, more intermediate storage and thus slower infiltration.

\section{PRECIPITATION REGIME (P FACTOR)}

The precipitation regime influences the rates of infiltration, percolation and groundwater flow and thus con- taminant transport in the aquifer (Daly et al. 2002). The $\mathrm{P}$ factor considers the quantity and intensity of precipitation events based on the daily precipitation amount for at least a 30-year period. Higher rainfall quantities and intensities mean more surface flow, higher transport velocities, shorter transit times, more turbulent flow, more effective transport of sediments, microbial pathogens and particle-bound chemical contaminants, mobilisation of DNAPLs (Dense Non-Aqueous Phase Liquids), etc., and thus higher vulnerability.

Two sub-factors should be considered to describe the number of major and extreme precipitation events that enable significant contaminant mobilisation and rapid transport: The rd sub-factor indicates the number of days with major rain quantities $(20-80 \mathrm{~mm} /$ day $)$, while the se sub-factor indicates the number of extreme storm events ( $>80 \mathrm{~mm} /$ day).

\section{KARST SATURATED ZONE (K FACTOR)}

The $\mathrm{K}$ factor represents the predominantly lateral groundwater flow in the saturated zone of the karst aquifer towards the spring or well. This factor needs to be considered for source vulnerability mapping, together with the three factors included in the resource vulnerability assessment ( $\mathrm{O}, \mathrm{C}$ and $\mathrm{P})$. The $\mathrm{K}$ factor does not only consider the degree of karstification, but mainly describes the dynamics of groundwater flow and how a particular zone is connected to the spring or well, emphasized and implemented also by Andreo et al. (manuscript in preparation).

In karst aquifers, underground flow paths are often not known. Also the classification of the karstification degree can be very subjective. Therefore, the detailed distribution of the $\mathrm{K}$ factor is difficult to map.

Size, connection and density of groundwater flow passages is a reliable source of information on the karst network, however, even a relatively small degree of karstification (e.g. conduits $5 \mathrm{~cm}$ wide and inaccessible to cavers) can result in very rapid flow and contaminant transport without significant attenuation.

Groundwater divides in karst aquifer systems are often not identical to topographic divides and are often difficult to determine. Furthermore, the position of groundwater divides is often not stable but may vary for several hundreds of metres or even kilometres as a function of the hydraulic conditions (Ravbar \& Goldscheider 2006). However, the size of a catchment is particularly crucial for source vulnerability assessment. In addition, catchments of several individual springs often overlap or are hydraulically connected over long distances.

The $\mathrm{K}$ factor should ideally reflect the following aspects (after Goldscheider et al. 2001; Daly et al. 2002; Brouyère 2004): 
- the travel time of a contaminant arrival at the source,

- the relative quantity of contaminants that arrive at the source,

- the contaminant concentration at the source and

- the duration of a contamination of the source.

The evaluation of the $\mathrm{K}$ factor considers three subfactors and includes information on groundwater travel time, variability of the drainage divides and information on underground water flow paths. Duration of a contamination could be an optional aspect.

The $t$ sub-factor considers the groundwater travel time in the saturated zone during high-flow conditions. The proposed classes are $<1$ day, $1-10$ days and $>10$ days, but these limits could be adapted to national legislation. Travel times can best be obtained from artificial tracer tests, if possible supplemented by geological, speleologi$\mathrm{cal}$ and natural tracer data. Due to aquifer heterogeneity, it is very difficult to draw precise isochrones. Nevertheless, travel times should be included in the assessment scheme using the best possible estimates.

The $r$ sub-factor expresses the degree of connection and contribution of different parts of the aquifer system to the source. The proposed assessment scheme considers the hydrogeological structure of the aquifer system by distinguishing between inner, intermediate and outer zones. The Irish Groundwater Protection Schemes use a similar system, but define 100 days as the limit between an inner and an outer zone (DoELG/EPA/GSI 1999). The inner zone comprises parts of the system that always contribute to the spring and that are directly connected to the spring. The inner zone is classified as most vulnerable.
The outer zone comprises parts of the system that contribute only marginally to the spring discharge (e.g. because they essentially drain towards another spring), areas that contribute only temporarily (e.g. during high water conditions), areas that are indirectly connected to the spring (e.g. because they are separated by an aquiclude), as well as areas for which we are not sure if they contribute to the source. Very remote parts of a spring catchment could also be included into the outer zone. The outer zone is classified as less vulnerable; a moderate vulnerability is assigned to intermediate situations. The information required for the $r$ sub-factor assessment can also be obtained from tracer tests and general hydrogeological considerations.

The $\mathrm{n}$ sub-factor indicates the presence of an active conduit network and assigns higher vulnerability to the wider area above those conduits. In many cases, such information is not available, and it is widely known that the absence of explorable conduits does not mean that there are no conduits. However, if there is direct evidence about active groundwater flow paths, the vulnerability assessment can be improved by including this information.

\section{SOURCE INTRINSIC VULNERABILITY ASSESSMENT}

Source vulnerability is obtained by combining the resource vulnerability assessment and the $\mathrm{K}$ factor vulnerability evaluation (Fig. 2). The source vulnerability map can be used as a basis for the delineation of source protection zones.

\section{SLOVENE APPROACH TO CONTAMINATION RISK MAPPING}

Vulnerability mapping is not always a sufficient criterion for proper land use planning, since it does not show the degree to which the aquifer is already under pressure, and how important the groundwater is for water supply or other purposes. On the basis of the conceptual framework proposed by COST Action 620 (De Ketelaere \& Daly 2004), the Slovene Approach provides a comprehensive risk analysis, which takes into account three elements: the intrinsic vulnerability of the groundwater resource or source, the contamination hazards, and the importance of the resource or source.

\section{HAZARD ASSESSMENT}

The goal of hazard mapping is to identify and illustrate the locations and types of human activities that pose a threat to groundwater quality. The hazard evaluation considers the type, noxiousness and quantity of the contaminants, as well as the likelihood of a contaminant release (De Ketelaere et al. 2004). The hazard level is achieved by assessing the socalled hazard weighting, ranking and reduction values.

The weighting factor $(\mathrm{H})$ distinguishes hazard harmfulness on the basis of a qualitative comparison of the potential damage to the groundwater or source. The main criteria for weighting different hazards concern the toxicity of relevant substances associated with each type of hazard as well as their properties regarding solubility and mobility. A detailed table of the weighting values for different hazard types, ranging between 10 and 100, can be found in the Final Report of COST Action 620, p. 9596 (De Ketelaere et al. 2004). 
SLOVENE APPROACH

INTRINSIC VULNERABILITY

\begin{tabular}{|c|c|c|c|c|c|c|c|c|}
\hline \multicolumn{5}{|c|}{ O factor } & \multicolumn{4}{|c|}{$\mathrm{O}$ score $=\mathrm{Os}+\mathrm{OL}$} \\
\hline \multirow{2}{*}{\multicolumn{2}{|c|}{ Soil (Os) }} & \multicolumn{3}{|c|}{ Texture, structure } & \multirow{2}{*}{\multicolumn{2}{|c|}{\begin{tabular}{|c|} 
O score \\
1 \\
\end{tabular}}} & \multirow{2}{*}{\multicolumn{2}{|c|}{\begin{tabular}{|c|} 
Protection value \\
Very low \\
\end{tabular}}} \\
\hline & & \begin{tabular}{|c|}
$\begin{array}{c}\text { Loamy, } \\
\text { silty }\end{array}$ \\
\end{tabular} & \multicolumn{2}{|c|}{$\begin{array}{l}\text { Clayey, } \\
\text { sandy }\end{array}$} & & & & \\
\hline \multirow{4}{*}{ 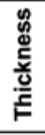 } & $>1 \mathrm{~m}$ & 5 & 5 & & \multicolumn{2}{|c|}{2} & Low & \multirow{3}{*}{$\frac{n}{\frac{1}{2}}$} \\
\hline & $(0.5-1 \mathrm{~m}]$ & 3 & 2 & & \multicolumn{2}{|c|}{$(2-4]$} & Moderate & \\
\hline & $(0.2-0.5 \mathrm{~m}]$ & 1 & 0 & & \multicolumn{2}{|c|}{$(4-8]$} & High & \\
\hline & {$[0-0.2 \mathrm{~m}]$} & 0 & 0 & & \multicolumn{2}{|c|}{$(8-15]$} & Extreme & \\
\hline \multicolumn{5}{|c|}{ Lithology (OL) } & \multicolumn{4}{|c|}{$\mathrm{OL}=\mathrm{Layer}$ index value $\times \mathrm{cn}$} \\
\hline \multicolumn{5}{|c|}{ Lithology and fracturation (ly) Value } & \multirow{3}{*}{\multicolumn{4}{|c|}{ Layer index $=\Sigma(l y \times m)$}} \\
\hline & lay & & & 1500 & & & & \\
\hline $\mathrm{Si}$ & it & & & 1200 & & & & \\
\hline \multicolumn{4}{|c|}{$\begin{array}{l}\text { Marl and non-fissured } \\
\text { metapelite and igneous rock }\end{array}$} & 1000 & \multirow{4}{*}{ 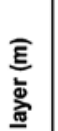 } & & Layer index V & Value \\
\hline \multicolumn{4}{|c|}{ Marly limestone } & 500 & & & {$[0-250]$} & 1 \\
\hline \multirow{2}{*}{\multicolumn{4}{|c|}{$\begin{array}{l}\text { Fissured metapelite } \\
\text { and igneous rock }\end{array}$}} & 400 & & & $250-1000]$ & 2 \\
\hline & & & & & & & 1000 - 2500] & 3 \\
\hline \multicolumn{4}{|c|}{$\begin{array}{l}\text { Cemented or non-fissured } \\
\text { conglomerate and breccia }\end{array}$} & 100 & \multirow{4}{*}{ 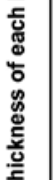 } & & $500-10000]$ & 4 \\
\hline \multicolumn{4}{|c|}{ Sandstone } & 60 & & & $>10000$ & 5 \\
\hline \multicolumn{4}{|c|}{$\begin{array}{l}\text { Scarcely cemented or fissured } \\
\text { conglomerate and breccia }\end{array}$} & 40 & & & & \\
\hline \multicolumn{4}{|c|}{ Sand and gravel } & 10 & & & & \\
\hline \multicolumn{4}{|c|}{ Permeable basalt } & 5 & f & & nditions (cn) & Value \\
\hline \multicolumn{4}{|c|}{ Fissured carbonated rocks } & 3 & & & Confined & 2 \\
\hline & arstified rocks & & & 1 & & & emi-confined & 1.5 \\
\hline & xtremly karstifi & ed areas & & 0.2 & & & on-confined & 1 \\
\hline
\end{tabular}

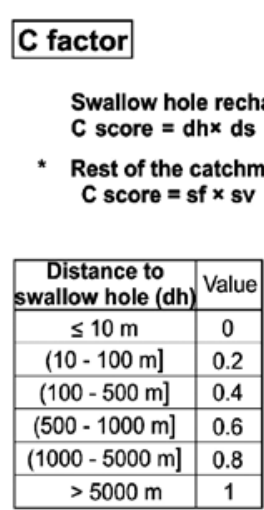

* $\mathrm{C}$ score equals 1 , when water is discharging

outside karst,

** $>5 \mathrm{~km}$ upstream,

ds value is 0.25 .

\begin{tabular}{|c|c|}
\hline C score & Reduction of protection \\
\hline$[0-0.2]$ & Extreme \\
\hline$(0.2-0.4]$ & High \\
\hline$(0.4-0.6]$ & Moderate \\
\hline$(0.6-0.8]$ & Low \\
\hline$(0.8-1]$ & Very low \\
\hline
\end{tabular}

\begin{tabular}{|l|l|}
\hline Distance to sinking \\
Value
\end{tabular} Temporal
variability (tv) \begin{tabular}{c|c|c|c|c|}
\hline$\leq 10 \mathrm{~m}$ & $0^{* *}$ \\
\hline$(10-100 \mathrm{~m}]$ & 0.5 \\
\hline$(10-100 \mathrm{~d} / \mathrm{y}$ & 0 \\
\hline
\end{tabular} \begin{tabular}{ll|l|l|l|l|l|l|}
$>100 \mathrm{~m}$ & 0.75 & $\mathrm{~d} / \mathrm{y}$ & 0.25 \\
\hline
\end{tabular}

\begin{tabular}{|r|c|c|c|c|}
\hline \multicolumn{5}{|c|}{ Slope and vegetation (sv) } \\
\hline \multirow{2}{*}{ Slope } & \multicolumn{4}{|c|}{ Vegetation cover } \\
\cline { 2 - 5 } & Less dense & Dense & Less dense & Dense \\
\hline$\leq 8 \%$ & 0.7 & 0.8 & 1 & 1 \\
\hline $8-31 \%]$ & 0.6 & 0.7 & 0.95 & 1 \\
\hline$>31 \%$ & 0.5 & 0.6 & 0.9 & 0.95 \\
\hline & $\begin{array}{c}\text { Less permeable or } \\
\text { impermeable surface }\end{array}$ & $\begin{array}{c}\text { Permeable } \\
\text { surface }\end{array}$ \\
\hline
\end{tabular}

\begin{tabular}{|l|c|c|c|}
\hline \multirow{2}{*}{$\begin{array}{c}\text { Surface morphologic } \\
\text { features (sf) }\end{array}$} & \multicolumn{3}{|c|}{ Subsoil layers } \\
\cline { 2 - 4 } & Absent & Permeable & Impermeable \\
\hline Developed karst features & 0.25 & 0.5 & 0.75 \\
\hline $\begin{array}{l}\text { Scarcely developed } \\
\text { or dissolution features }\end{array}$ & 0.5 & 0.75 & 1 \\
\hline Fissured karst & 0.75 & 0.75 & 1 \\
\hline Absence of karst features & 1 & 1 & 1 \\
\hline
\end{tabular}

\begin{tabular}{|c|c|c|c|c|c|}
\hline \multirow{2}{*}{\multicolumn{2}{|c|}{ P factor }} & P score & Reduction of pr & rotection & \multirow{6}{*}{$\sum_{0}^{\infty}$} \\
\hline & & {$[0.36-0.5]$} & \multicolumn{2}{|l|}{ Extreme } & \\
\hline \multirow{4}{*}{\multicolumn{2}{|c|}{ P score $=r d \times$ se }} & $(0.5-0.6]$ & \multicolumn{2}{|l|}{ High } & \\
\hline & & $(0.6-0.7]$ & \multicolumn{2}{|c|}{ Moderate } & \\
\hline & & $(0.7-0.8]$ & \multicolumn{2}{|l|}{ Low } & \\
\hline & & $(0.8-1]$ & \multicolumn{2}{|l|}{ Very low } & \\
\hline \multicolumn{5}{|l|}{ Rainy days (rd) } & \\
\hline \multirow{2}{*}{$\begin{array}{c}\text { Average annual number } \\
\text { of days } 20-80 \mathrm{~mm} / \mathrm{d} \\
{[0-10]}\end{array}$} & \multirow{2}{*}{ Value } & \multicolumn{3}{|c|}{ Storm events (se) } & \\
\hline & & \multicolumn{2}{|c|}{$\begin{array}{c}\text { Average annual number } \\
\text { of days }>80 \mathrm{~mm} / \mathrm{d}\end{array}$} & Value & \\
\hline$(10-20]$ & 0.9 & \multicolumn{2}{|c|}{$[0-1]$} & 1 & \\
\hline$(20-50]$ & 0.8 & \multicolumn{2}{|c|}{$(1-5]$} & 0.8 & \\
\hline$>50$ & 0.6 & \multicolumn{2}{|r|}{$>5$} & 0.6 & \\
\hline
\end{tabular}

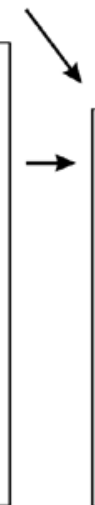

Resource vulnerability

Resource score $=\mathbf{O}$ score $\times \mathbf{C}$ score $\times \mathbf{P}$ score

\begin{tabular}{|c|c|c|c|}
\hline $\begin{array}{c}\text { Resource } \\
\text { score }\end{array}$ & $\begin{array}{c}\text { Resource } \\
\text { index }\end{array}$ & Vulnerability classes & \\
\hline$[0-0.5]$ & 1 & Extreme & \\
\hline$(0.5-1]$ & 2 & High & $<4$ \\
\hline$(1-2]$ & 3 & Moderate & ऊ \\
\hline$(2-4]$ & 4 & Low & w \\
\hline$(4-15]$ & 5 & Very low & \\
\hline
\end{tabular}

\begin{tabular}{|c|c|c|c|c|c|}
\hline \multirow{2}{*}{ K factor } & & K score & $\mathbf{K}$ index & Vulnerability classes & \multirow{4}{*}{$\frac{5}{2}$} \\
\hline & & {$[0-1]$} & 0 & High & \\
\hline \multirow{2}{*}{\multicolumn{2}{|c|}{$K$ score $=t \times n \times r$}} & $(1-30]$ & 1 & Moderate & \\
\hline & & $(30-125]$ & 2 & Low & \\
\hline \multirow[b]{2}{*}{$\begin{array}{l}\text { Groundwater } \\
\text { travel time (t) }\end{array}$} & \multirow[b]{2}{*}{ Value } & \multicolumn{2}{|c|}{\begin{tabular}{|c|}
$\begin{array}{c}\text { Information on } \\
\text { karst network (n) }\end{array}$ \\
Value \\
\end{tabular}} & $\begin{array}{l}\text { Connection and } \\
\text { contribution }(r)\end{array}$ & Value \\
\hline & & \multirow{3}{*}{$\begin{array}{l}\text { Water conduit, } \\
\text { clear evidence } \\
\text { Intermediate, } \\
\text { unknown }\end{array}$} & 1 & \multirow{2}{*}{$\begin{array}{c}\leq 1 \%, \text { temporary, } \\
\text { remote, not sure } \\
(1-10 \%], \\
\text { intermediate }\end{array}$} & 5 \\
\hline$\leq 1 \mathrm{~d}$ & 1 & & & & \multirow[t]{2}{*}{3} \\
\hline$(1-10 d]$ & 3 & & 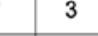 & $\begin{array}{c}\text { intermediate } \\
>10 \% \text { always }\end{array}$ & \\
\hline$>10 d$ & 5 & Only fracture & 5 & direct, sure & 1 \\
\hline
\end{tabular}

\section{Source vulnerability}

Source score $=$ Resource index $+\mathbf{K}$ index

\begin{tabular}{|c|c|c|c|}
\hline $\begin{array}{c}\text { Source } \\
\text { score }\end{array}$ & $\begin{array}{c}\text { Source } \\
\text { index }\end{array}$ & Vulnerability classes & H \\
\hline $1-2$ & 2 & High & Moderate \\
\hline 3 & 3 & Low & ஸ \\
\hline$\geq 4$ & 4 & \multicolumn{2}{|c|}{} \\
\hline
\end{tabular}

Fig. 2: The Slovene Approach intrinsic vulnerability assessment scheme. 


\begin{tabular}{|c|c|c|c|c|c|c|c|}
\hline \multirow{2}{*}{ No. } & \multirow{2}{*}{ Hazards } & \multirow{2}{*}{ Classification criteria } & \multicolumn{5}{|c|}{ Ranking factor (Qn) } \\
\hline & & & 0.8 & 0.9 & 1 & 1.1 & 1.2 \\
\hline 1. & Infrastructural development & & & & & & \\
\hline 1.1. & Waste water (urbanisation) & Population density (inhabitant/km²) & $<10$ & {$[10-50)$} & {$[50-100)$} & {$[100-500)$} & $\geq 500$ \\
\hline 1.2. & Waste disposal (unprotected/illegal) & Volume $\left(1000 \mathrm{~m}^{3}\right)$ & $<0.1$ & {$[0.1-1)$} & {$[1-5)$} & {$[5-10)$} & $\geq 10$ \\
\hline \multirow[t]{2}{*}{1.3} & Fuels & No. Pumps & $<2$ & {$[2-5)$} & {$[5-10)$} & {$[10-15)$} & $\geq 15$ \\
\hline & & Amount of storage $(t)$ & $<0.5$ & {$[0.5-1)$} & {$[1-5)$} & {$[5-10)$} & $\geq 10$ \\
\hline \multirow[t]{2}{*}{1.4} & Transport and traffic, roads & No. Vehicles/day & $<100$ & {$[100-1,000)$} & {$[1,000-5,000)$} & {$[5,000-10,000)$} & $\geq 10,000$ \\
\hline & Railway & No. Trains/day & $<10$ & {$[10-25)$} & {$[25-50)$} & {$[50-100)$} & $\geq 100$ \\
\hline 1.5. & Recreational facilities & No. Visitors/day & $<10$ & {$[10-100)$} & {$[100-500)$} & {$[500-1,000)$} & $\geq 1,000$ \\
\hline 1.6.1. & Graveyard & Size $\left(1000 \mathrm{~m}^{2}\right)$ & $<5$ & {$[5-10)$} & {$[10-50)$} & {$[50-100)$} & $\geq 100$ \\
\hline 1.6.5. & Military installations and dereliction & Size $\left(\mathrm{km}^{2}\right)$ & $<1$ & {$[1-5)$} & {$[5-10)$} & {$[10-25)$} & $\geq 25$ \\
\hline 2. & Industrial activities & & & & & & \\
\hline 2.1. & Mining (in operation and abandoned) & Volume $\left(1000 \mathrm{~m}^{3}\right)$ & $<0.1$ & {$[0.1-1)$} & {$[1-5)$} & {$[5-10)$} & $\geq 10$ \\
\hline 2.2 . & Excavation sites & Volume $\left(1000 \mathrm{~m}^{3}\right)$ & $<0.1$ & {$[0.1-1)$} & {$[1-5)$} & {$[5-10)$} & $\geq 10$ \\
\hline 2.4 & Industrial plants (none mining) & Water consumption (1000 mlyear) & $<1$ & {$[1-5)$} & {$[5-10)$} & {$[10-50)$} & $\geq 50$ \\
\hline 2.5. & Power plants (wind turbines) & Power (kw) & $<50$ & {$[50-100)$} & {$[100-500)$} & {$[500-1,000)$} & $\geq 1,000$ \\
\hline 2.6. & Industrial storage & Volume $\left(1000 \mathrm{~m}^{3}\right)$ & $<0.1$ & {$[0.1-1)$} & {$[1-5)$} & {$[5-10)$} & $\geq 10$ \\
\hline 2.7 . & Diverting and treatment of waste water & Capacity in PU (Person unit) & $<500$ & {$[500-1,000)$} & {$[1,000-1,500)$} & {$[1,500-2,000)$} & $\geq 2,000$ \\
\hline 3. & Livestock and agriculture & & & & & & \\
\hline \multirow[t]{2}{*}{3.1.} & Livestock & Livestock in LU (Livestock unit) & $<5$ & {$[5-10)$} & {$[10-50)$} & {$[50-100)$} & $\geq 100$ \\
\hline & & $\begin{array}{l}\text { Livestock density } \\
\text { (LU/ha cultivated land) }\end{array}$ & $<0.5$ & {$[0.5-1)$} & {$[1-1.5)$} & {$[1.5-2)$} & $\geq 2$ \\
\hline \multirow[t]{5}{*}{3.2.} & Agriculture & Livestock in LU (Livestock unit) & $<5$ & {$[5-10)$} & {$[10-50)$} & {$[50-100)$} & $\geq 100$ \\
\hline & & $\begin{array}{l}\text { Livestock density } \\
\text { (LU/ha cultivated land) }\end{array}$ & $<0.5$ & {$[0.5-1)$} & {$[1-1.5)$} & {$[1.5-2)$} & $\geq 2$ \\
\hline & & $\begin{array}{l}\text { Annual consumption of manure or } \\
\text { liquid manure }\left(\mathrm{m}^{3} / \mathrm{ha} \text { cultivated land) }\right.\end{array}$ & $<1$ & {$[1-5)$} & {$[5-10)$} & {$[10-15)$} & $\geq 15$ \\
\hline & & $\begin{array}{l}\text { Annual consumption of mineral } \\
\text { fertilizers ( } \mathrm{kg} / \text { ha cultivated land) }\end{array}$ & $<1$ & {$[1-10)$} & {$[10-50)$} & {$[50-100)$} & $\geq 100$ \\
\hline & & $\begin{array}{l}\text { Annual consumption of pesticides } \\
\text { (kg/ha cultivated land) }\end{array}$ & $<1$ & {$[1-5)$} & {$[5-10)$} & {$[10-50)$} & $\geq 50$ \\
\hline
\end{tabular}

Fig. 3: Hazard ranking.

Hazards of the same type but with different characteristics (size, etc.) can be compared using a hazard ranking classification. According to COST Action 620, the ranking factor $(\mathrm{Qn})$ ranges between 0.8 and 1.2. The Slovene Approach provides ranking values for selected human activities, developed for Slovene circumstances (Fig. 3).

The reduction factor (Rf) expresses the probability of a contamination event to occur. Therefore, the technical status, level of maintenance, surrounding conditions, security measures and other factors should be considered. The values should range between 0 and 1 . The reduction factor is 1 when no such information is available. Lower values imply positive information concerning the reduction of the likelihood. However, it is recommended to use small deviations from 1 in order to avoid minimi- zation of the effects of hazards with high toxic potential (De Ketelaere et al. 2004).

For each activity its hazard level is assessed by multiplying the hazard weighting value $\mathrm{H}$, the ranking factor Qn and the reduction factor Rf (Fig. 4).

\section{EVALUATING THE IMPORTANCE OF A GROUNDWATER SOURCE OR RESOURCE}

The importance of a groundwater source or resource depends on its actual or potential use for drinking water purpose, agriculture or other human activities, and on the ecological value of the ground or spring water and associated surface waters. The quantity of the used water and the size of the population and animal stock depending on this water also determine the importance. The irreplaceability also needs to be considered, i.e., is it the 


\section{SLOVENE APPROACH}

\section{HAZARD}

\section{Hazard score $=\mathbf{H} \times \mathbf{Q n} \times \mathbf{R f}$}

\begin{tabular}{|c|c|c|c|}
\hline $\begin{array}{l}\text { Hazard } \\
\text { score }\end{array}$ & $\begin{array}{l}\text { Hazard } \\
\text { index }\end{array}$ & Hazard level & \multirow{7}{*}{$\frac{0}{\frac{\alpha}{4}} \frac{0}{4}$} \\
\hline 0 & 5 & No hazard & \\
\hline$(0-24]$ & 4 & Very low & \\
\hline$(24-48]$ & 3 & Low & \\
\hline$(48-72]$ & 2 & Moderate & \\
\hline$(72-96]$ & 1 & High & \\
\hline$(96-120]$ & 0 & Extreme & \\
\hline
\end{tabular}

Fig. 4: Hazard level assessment. only possible water source, or are there other available options? On the basis of these criteria, a simple assessment scheme for the importance of karst water sources and resources is proposed (Fig. 5). Four sub-factors need to be evaluated and summed up. The importance evaluation enables prioritisation procedure for protection and sanitation programme on a local or regional scale.

\section{RISK ASSESSMENT}

The "risk intensity" is obtained by combining the vulnerability and the hazard assessment. The highest risk of groundwater contamination is present where dangerous hazards occur in a highly vulnerable zone. The "total risk" additionally considers the importance of the water resource and source (Fig. 6). A high risk consequently indicates the necessity to act by changing land use practices or removing existing hazards.

\section{FIRST APPLICATION AND VALIDATION OF THE SLOVENE APPROACH}

\section{HYDROGEOLOGICAL CHARACTERISTICS OF THE TEST SITE}

The catchment of the Podstenjšek springs stretches over about $9 \mathrm{~km}^{2}$ in the Upper Pivka valley in southwestern Slovenia. The catchment area occupies moderately karstified Cenomanian limestones and limestone breccias, and Palaeogene limestones that are over-thrusted to the impermeable Eocene flysch (Šikić \& Pleničar 1975), thus forming a shallow karst aquifer. Due to the fast and strong hydrologic variations in response to precipitation events or snowmelt, groundwater table fluctuates for several tens of meters. There is no permanent surface stream recharging the springs however, owing to groundwater fluctuations and weak connections between different karst conduits, two intermittent lakes (Šembijsko Jezero, Nariče) appear whenever groundwater level is sufficiently high. In the area of the intermittent lakes, alluvial deposits can be found, and in the uplifted dry valley at the outskirts of the catchment, there is periglacial material deposited in the dolines.

Shallow chromic Cambisol interwoven with Rendzina layers appears in patches. The thickest soil layers can be found in the bottom of the concave relief shapes, while the rest of the surface is pretty rocky. Most of the area is overgrown with forest and meadows or is used for low-intensity agriculture.

For the catchment delineation and application of the Slovene Approach, a comprehensive study was done, including tracer tests, detail structural-lithological and geomorphological mapping, electrical resistivity imag- ing, as well as hazard mapping. Continuous monitoring of the springs' physico-chemical characteristics has been performed for the hydrograph analyses, water balance calculation and aquifer behaviour comprehension (Ravbar 2007).

\section{APPLICATION OF THE SLOVENE APPROACH AND RESULTS}

The proposed Slovene Approach has been first applied to the Podstenjšek springs catchment, thus allowing its development, completion and testing. Based on the geological and geomorphological settings, tracer test results and the springs' hydrodynamic behaviour the catchment can be subdivided into an inner and an outer zone. In the area that is always, directly and fully contributing to the discharge of the springs (i.e. the inner zone) the geomorphological features (karren, highly fractured areas, caves, karst edge) and outcrops along the roads where soil cover is absent or rarely exceeds $20 \mathrm{~cm}$ were identified as highly vulnerable. High degree of vulnerability is also assigned to the estavelle (shown in the zoomed inset) where occasional point recharge occurs. Moderate vulnerability has been assigned to the bare karst landscape or karst covered by shallow soils, as well as to the karren and dry valleys in the area of the partial or occasional contribution to the springs (i.e. the outer zone). The bottoms of intermittent lakes and dolines covered by thicker soils or sediments are of low vulnerability, as well as rest of the outer zone (Fig. 7). 


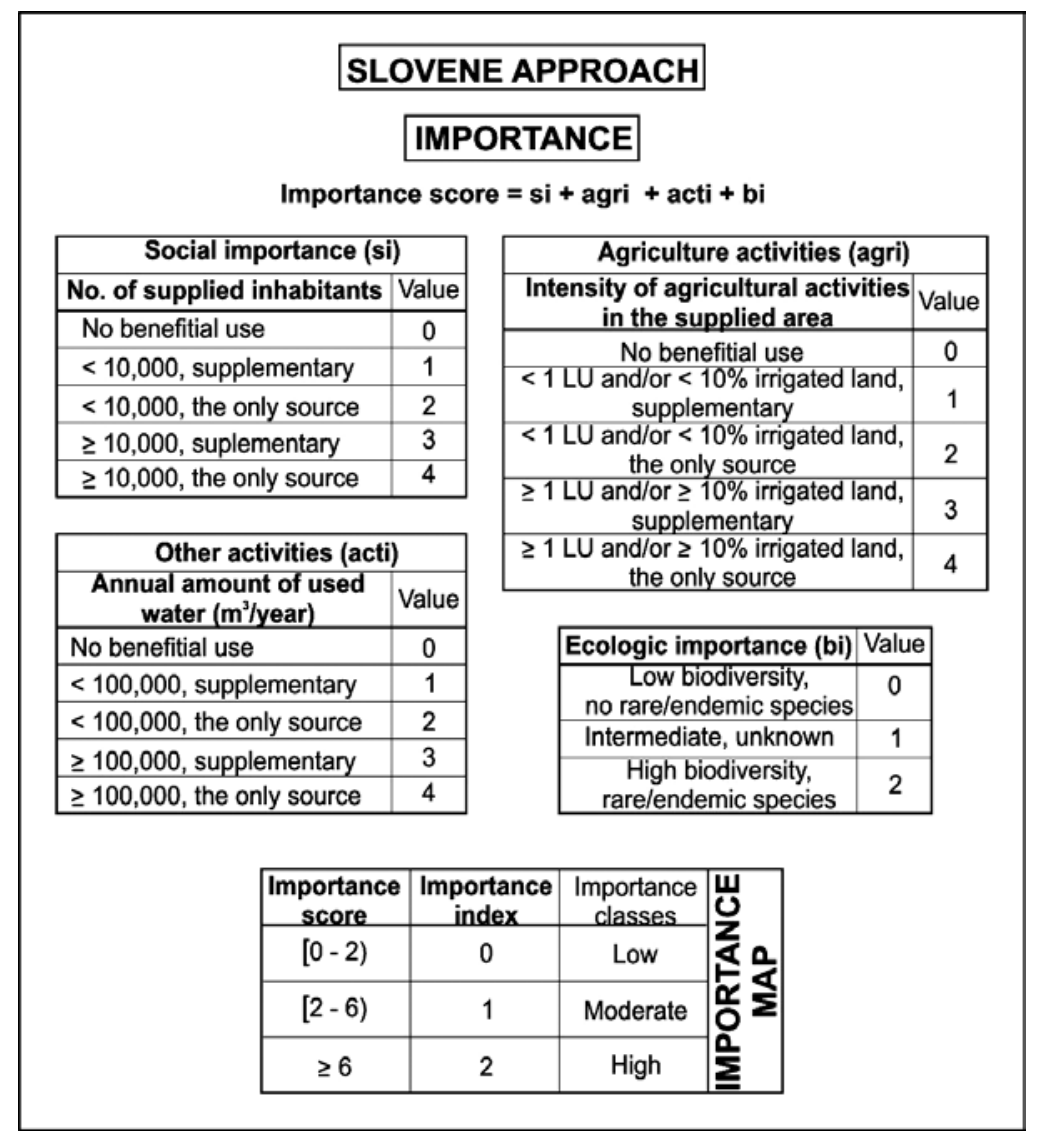

Fig. 5: Assessment scheme to evaluate the importance of a karst groundwater resource or source.

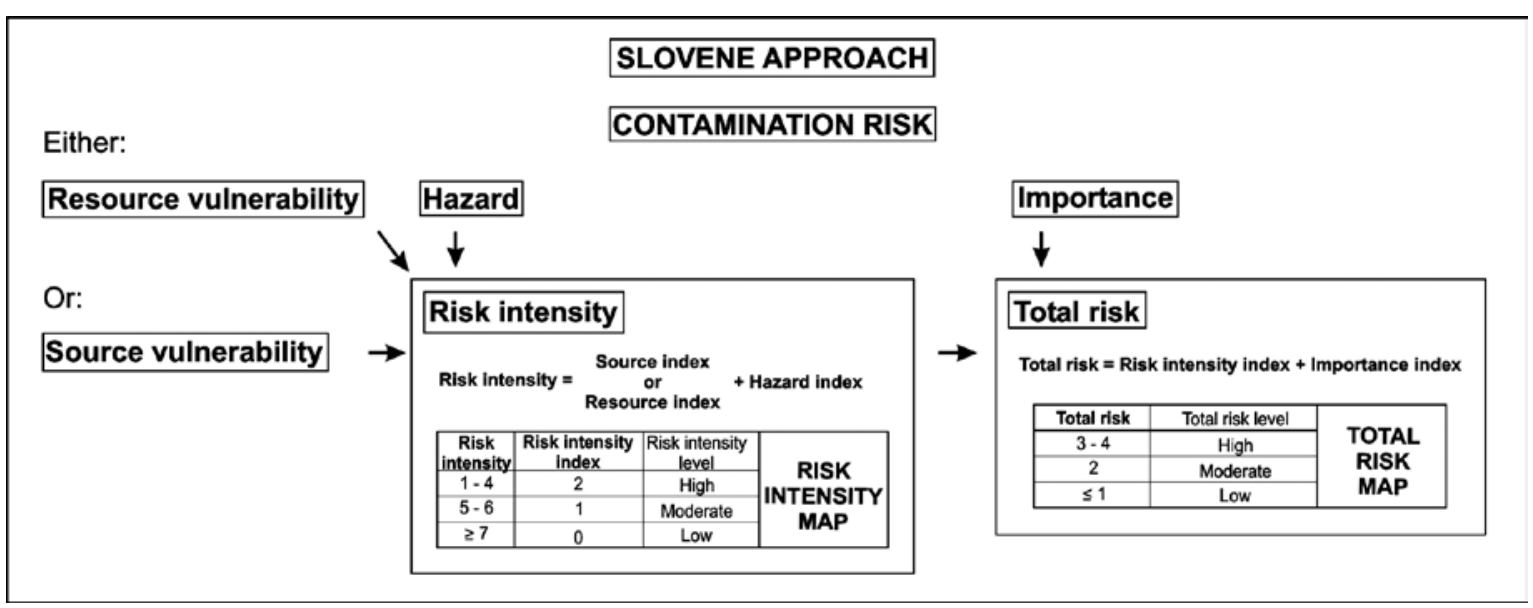

Fig. 6: The Slovene Approach to contamination risk assessment.

In the Šembije village, the only settlement in the catchment, about 200 inhabitants live. The houses have been linked to the public sewage system since 1998 and connected to the wastewater treatment plant located outside the catchment. The intensity of agricultural activity is relatively low. There are some smaller waste disposal and excavation sites. The hazards found in the test site are mainly classified as low or very low; however, in more than half of the area no hazards have been identified (Fig. 8).

The Podstenjšek water source supplies only a few hundred people and is scantily used for animal breeding and gardening. However, it is the only water source. Furthermore, the presence of Proteus Anguinus has been 

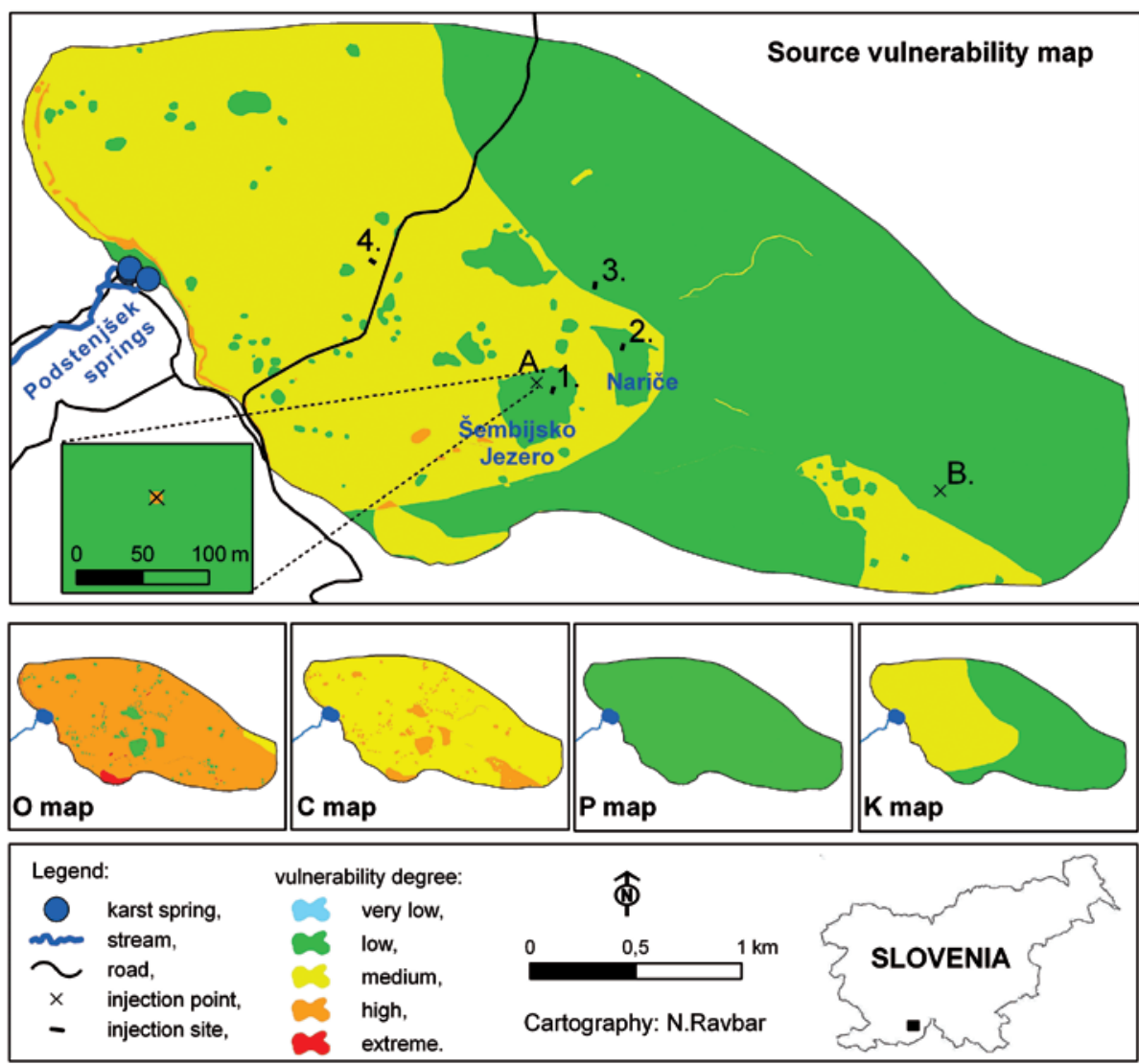

Fig. 7: Source vulnerability map of the Podstenjšek springs catchment, maps of the individual parameters and location of the validation points.
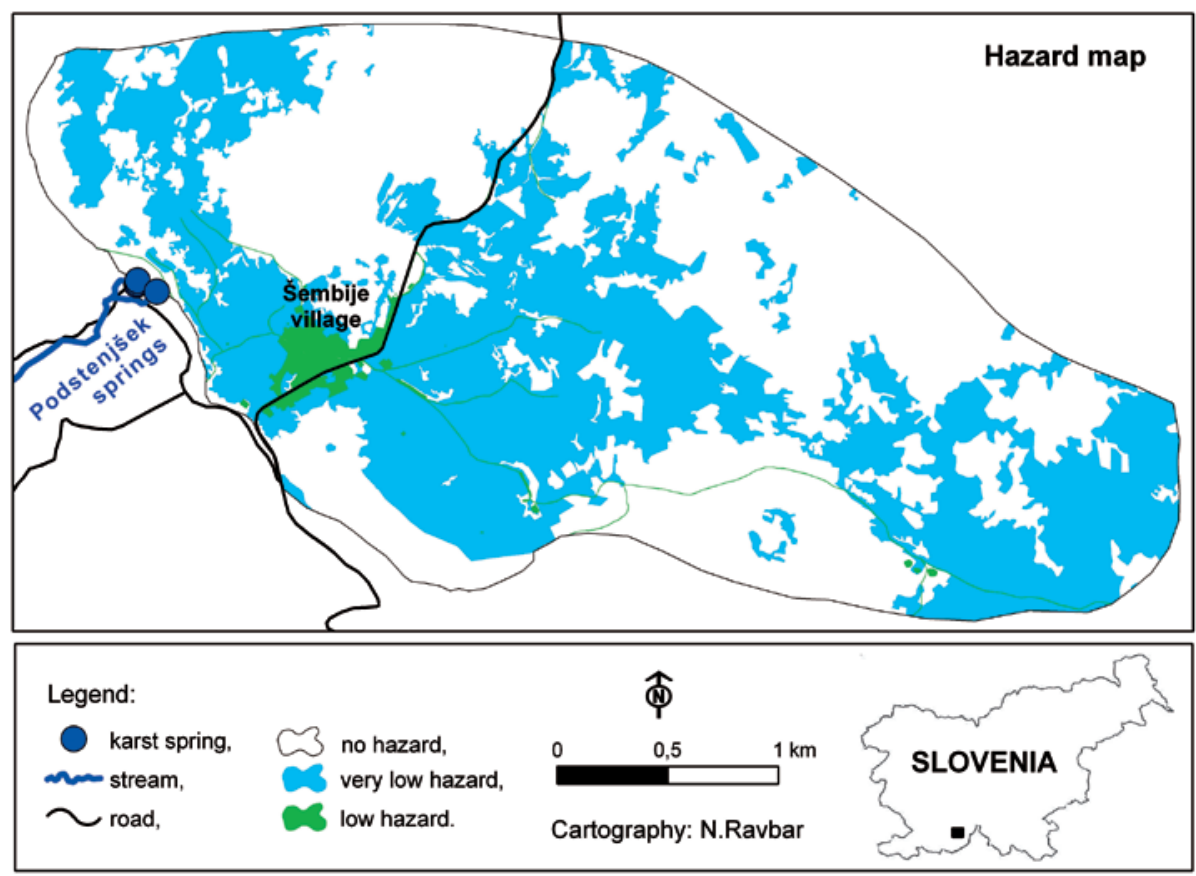

Fig. 8: Hazard map of the Podstenjšek springs catchment. reported in the nearby cave (Krivic et al. 1987). Therefore, importance of the source has been evaluated as medium. By superimposing source vulnerability, hazard and source importance maps, the total contamination risk evaluation has been obtained. In general, the risk degree strongly depends on the hazard level and its distribution. Most of the catchment is exposed to low risk; only urban areas, roads, dumps and excavation sites represent medium degree of contamination risk (Fig. 9).

\section{RELIABILITY OF THE RESULTS}

The source vulnerability map shows zones of low, medium and high degree of vulnerability, which can be the basis for the protection zoning. However, vulnerability maps are conservative simplifications of natural conditions and the results are influenced by diverse aspects (e.g. quality and accuracy of data, their interpretation, selection and evaluation of different parameters, etc.). Therefore the results need to be validated.

Goldscheider et al. (2001) proposed using tracer tests for the validation of vulnerability maps and considered three criteria that can be obtained from tracer breakthrough curves: the peak time (time of maximum tracer concentration), the recovery rate $(R)$, and the maximum concentration normalised by the injected tracer mass $(\mathrm{C} / \mathrm{M})$. This approach has three minor drawbacks: the time of first arrival is often more relevant for problems of water con- 

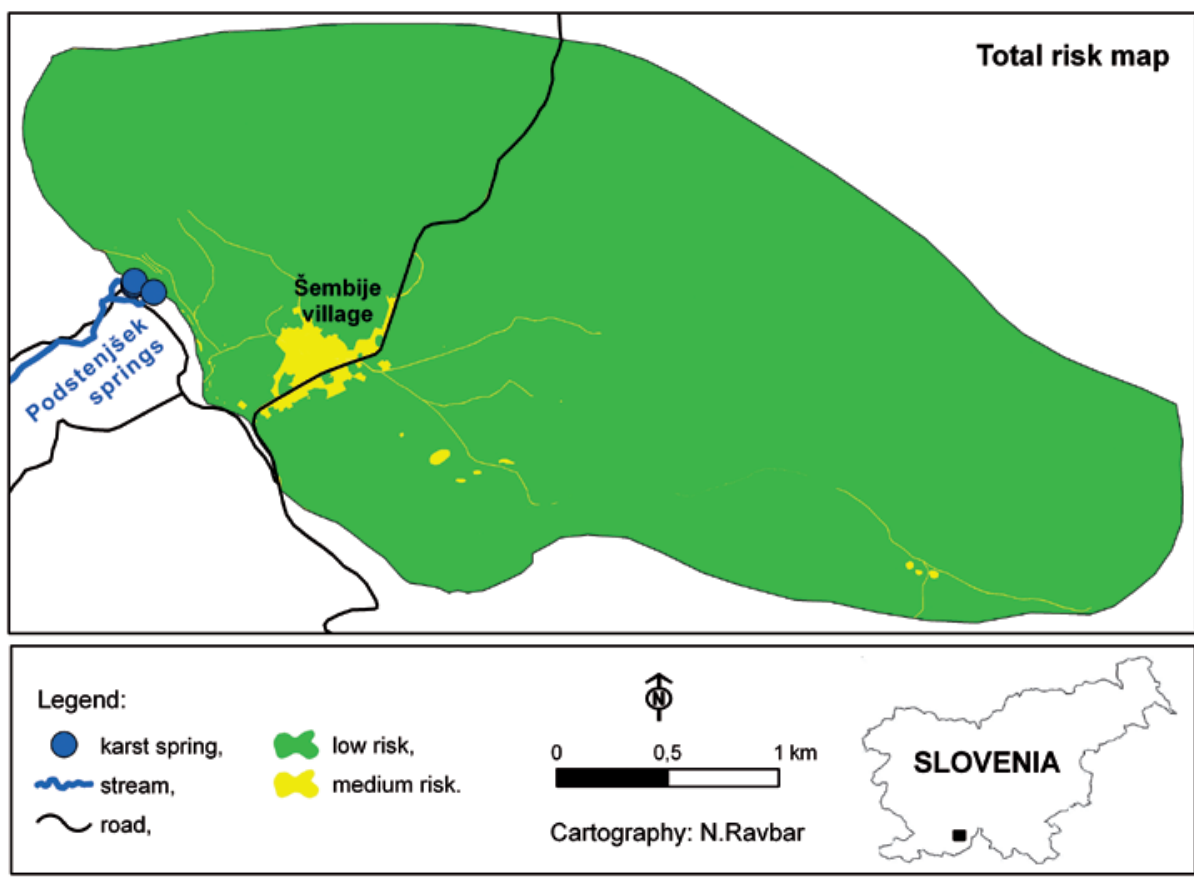

Fig. 9: Total risk map of the Podstenjšek water source.

tamination; $\mathrm{R}$ and $\mathrm{C} / \mathrm{M}$ are interdependent; and $\mathrm{R}$ depends directly on the spring discharge Q. Therefore, we propose to use only two modified validation criteria: the time of first tracer detection, and the normalized tracer recovery $R_{N}$, which is defined as:

$$
\mathrm{R}_{\mathrm{N}}=\frac{1}{\mathrm{M}} \int \mathrm{Cdt}=\frac{\mathrm{R}}{\mathrm{Q}}
$$

It is a way of expressing the tracer recovery independent of the spring discharge. When $\mathrm{R}_{\mathrm{N}}$ is used for validation, the same degree of vulnerability would be attributed to a small spring and to a big spring if the tracer breakthrough curves at both springs are similar, i.e. similar maximum concentration and duration of the tracer (or potential contamination event) appearance. The origin (injection point) presents high vulnerability for the observed target (most commonly a source), if rapid infiltration and fast flow in conduits are the dominant conditions. Resulting travel times are thus very short, minimizing also the sorption, degradation, cation exchange, dispersion and dilution of a solute matter. In such conditions the possible contamination would reach the water source very rapidly and its concentration at the outlet, as well as the relative quantity of the recovered tracer, would be high. In contrast, the origin (injection point) presents low vulnerability for the observed target (most commonly the source), if the tracer is mostly absorbed in the sediments and soil. Consequently, the possible contaminant arrival is retarded and its concentration significantly reduced or the contaminant does not arrive at all. Intermediate situations correspond to medium vulnerability (Fig. 10).

By carrying out two multi-tracer tests in the studied area, we examined and verified the adequacy of the obtained vulnerability map and gained additional information on the mechanism of potential contaminant transport under different hydrological conditions.

The first tracer test, carried out in March 2006, was made under high water conditions and was followed by several intense precipitation events so that immediate infiltration and transport of tracers towards the springs took place. Two tracers were injected; $94 \mathrm{~g}$ of sulforhodamine $B$ was injected in an estavelle that was empty at the time of injection (injection point $\mathrm{A}$ ) and $500 \mathrm{~g}$ of eosin was injected in karren (injection point B). The estavelle was characterised as highly vulnerable and the area below the Milanka mountain as of low vulnerability (Figs. 7 and 11).

Both tracers more or less simultaneously appeared three days after the injection in the Podstenjšek springs. Sulforhodamine B was detected in the springs' samples for few days with maximal concentration of $1.65 \mathrm{ppb}$ and appeared again in lower concentrations after the subsequent

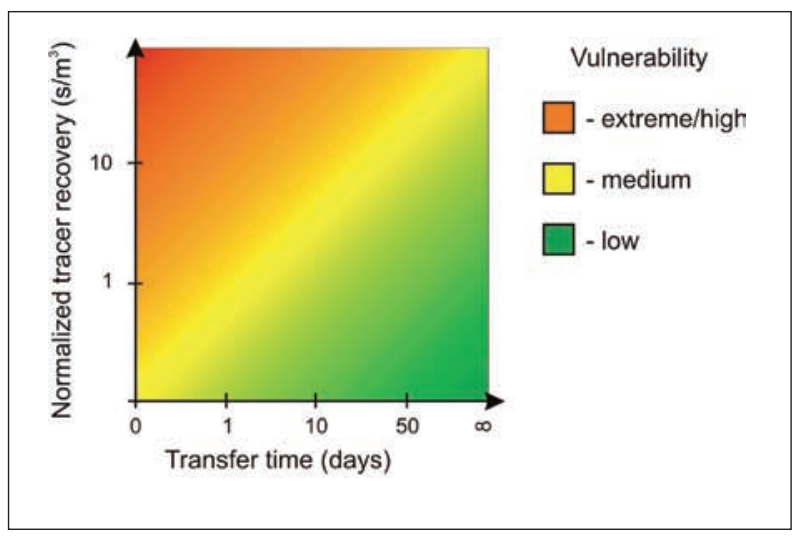

Fig. 10: Diagram setting up the tracer test results for source vulnerability validation purposes. Due to the lack of consensus regarding the vulnerability classification between different methods a universal class distribution is provided. To enable general applicability of the diagram definite boundaries between vulnerability classes are omitted. 
rainy events. Altogether $52.5 \%$ of the sulforhodamine B has been recovered. On the contrary, the eosin appearance does not show a typical breakthrough curve and only few samples were eosin positive. The peak concentration of $0.2 \mathrm{ppb}$ and the total recovery of $0.95 \%$ were observed at the Podstenjšek springs. The greater portion $(81.2 \%)$ flowed to the nearby Bistrica spring (Figs. 11 and 12).

The second experiment, carried out in November 2006, was made under low water conditions. A more in-

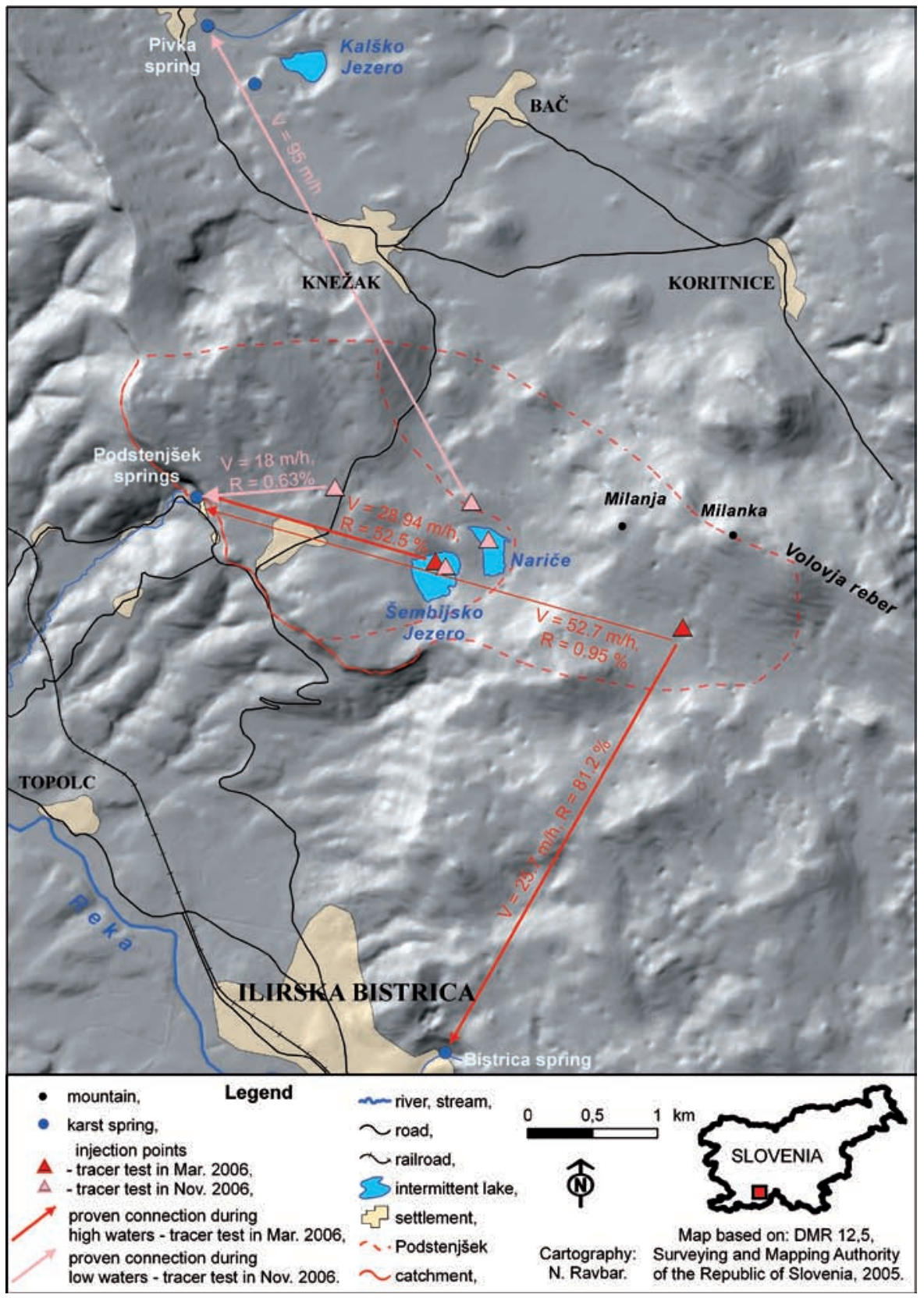

Fig. 11: Results of the two multi-tracer tests performed in the Podstenjšek spring catchment during high and low water conditions. tense rainy event did not occur until 15 days after the injection. Four tracers were injected in four locations. On the bottom of the Šembijsko Jezero $500 \mathrm{~g}$ of uranine was spread over several metres thick soil and sediment cover (injection site 1). Over the Nariče where soil and sediments occur in pockets and the limestone rock base outcrops in places $400 \mathrm{~g}$ of sulforhodamine $\mathrm{G}$ was spread (injection site 2). Two tracers were spread over the limestone surface, partially covered by scarce soil and vegetation cover. At injection site 3 a total of $5 \mathrm{~kg}$ of lithium chloride was used and at the injection site 4 a total of $5 \mathrm{~kg}$ of potassium iodide was used. The first three injection sites are classified as of low and the last one as of moderate vulnerability (Fig. 7).

Only iodide, used in injection site 4 was detected at the Podstenjšek springs (Fig. 12). It was first detected two days after the injection and its appearance lasted for additional two days with maximal concentration of $3.2 \mathrm{ppb}$. Altogether $0.63 \%$ of the injected iodide was recovered. Lithium was only detected in the Pivka spring and even after six months of sampling no fluorescent tracers have been detected in any of the observed springs (Fig. 11).

These results confirm the vulnerability assessment; the tracer injected in the area classified as highly vulnerable rapidly reached the spring, its concentrations and recovered quantities were high. The tracer injected on the area classified as moderately vulnerable rapidly reached the spring, the concentrations were high, but the recovered quantities very low. The tracers injected on areas classified as low vulnerability zones did not arrive at the spring at all or the tracer only arrived in small proportions and was detected in low concentrations. 


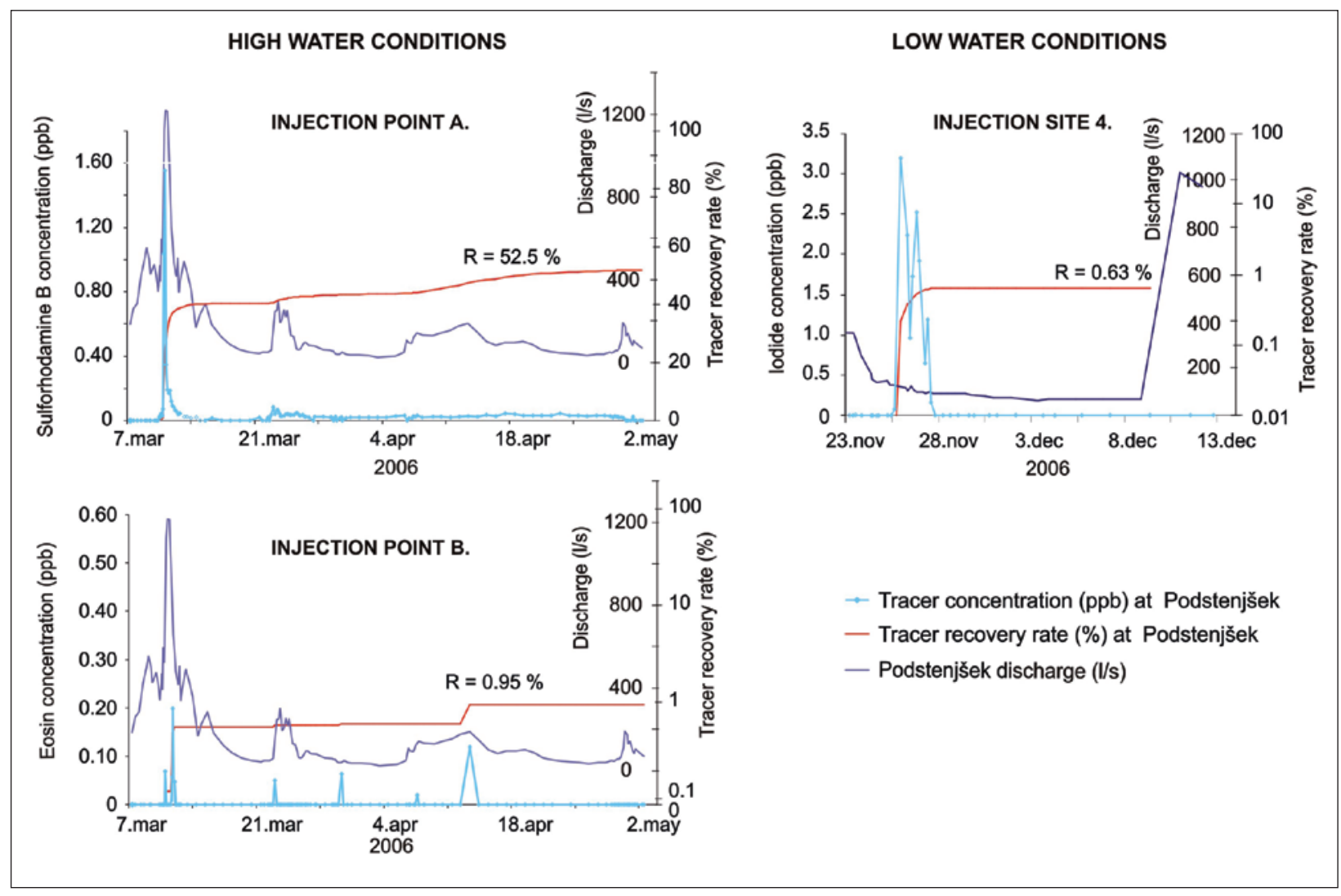

Fig. 12: Particular tracer appearance at the Podstenjšek spring (the location of the injection sites are shown on Fig. 7).

\section{CONCLUSION}

The proposed Slovene Approach is so far the most complete interpretation of the European Approach to vulnerability and risk mapping, as it can be used for both resource and source vulnerability mapping and also includes an assessment of contamination hazards, an evaluation of the value or importance of the groundwater, and different types of risk maps. The resulting maps can be used as a basis for the delineation of protection zones and other land use planning issues. Such maps could also be used to focus pollution investigations and pollution prevention inspections of high risk premises.

The test site application and validation with tracer tests confirmed that the intrinsic vulnerability map is plausible and reliable. Furthermore, the validation also justifies the integration of hydrological variability into vulnerability mapping: the tracers injected in sites of occasional direct infiltration during low flow conditions were not detected in any of the springs, but were absorbed by the soil and sediments, while the tracer in- jected during high flow conditions arrived at the springs. The hazard and risk maps also show that the water source is not at high risk. The few water quality analyses showing its high quality confirm this evaluation.

The study has shown the new Slovene Approach gives justified results and provides improved source protection zoning. Furthermore, we identified land mismanagement and proposed better practices for future planning.

Thus, the Slovene Approach could be proposed as the basis for the delineation of karst source protection zones and included to the state protection schemes. Although the method considers karst-specific infiltration conditions, it is not restricted solely to karst but can also be used in non-karst areas. Moreover, since we believe that vulnerability methods should not be limited to the individual countries' borders, the Slovene Approach could be a basis for the further work concerning groundwater protection elsewhere. 


\section{ACKNOWLEDGEMENTS}

The study was founded by the Slovene Ministry of Higher Education, Science and Technology in the frame of the Young Researchers Programme, and is a contribution to the UNESCO/IUGS IGCP 513 Project "Global Study of Karst Aquifers and Water Resources". Special thanks to Dr. Pierre-André Schnegg (University of Neuchâtel),
Hans Krafft (Nationalpark Berchtesgaden) and Borut Peric (Park Škocjanske jame) for lending us field fluorometers and an automatic sampler. The authors also acknowledge the help of Silvia Guglielmetti (University of Neuchâtel), Dr. Jesus Vías (University of Malaga) and Gregor Kovačič (University of Primorska).

\section{REFERENCES}

Andreo, B., Goldscheider, N., Vadillo, I., Vías, J.M., Neukum, Ch., Sinreich, M., Jiménez, P., Brechenmacher, J., Carrasco, F., Hötzl, H., Perles, J.M. \& F. Zwahlen, 2006: Karst groundwater protection: First application of a Pan-European Approach to vulnerability, hazard and risk mapping in the Sierra de Líbar (Southern Spain).- Science of the Total Environment 357, 54-73.

Brouyère, S., 2004: A quantitative point of view of the concept of vulnerability. In: Zwahlen, F. (ed.), COST Action 620. Vulnerability and Risk Mapping for the Protection of Carbonate (Karstic) Aquifers. Final report COST Action 620.- European Commission, Directorate-General for Research, 10-15, Brüssel, Luxemburg.

Daly, D., Dassargues, A., Drew, D., Dunne, S., Goldscheider N., Neale, S., Popescu, I.C. \& F. Zwahlen, 2002: Main concepts of the "European approach" to karst-groundwater-vulnerability assessment and mapping.- Hydrogeology Journal 10, 340-345.

De Ketelaere, D. \& D. Daly, 2004: Vulnerability in a Risk Framework. In: Zwahlen, F. (ed.), COST Action 620. Vulnerability and Risk Mapping for the Protection of Carbonate (Karstic) Aquifers. Final report COST Action 620.- European Commission, DirectorateGeneral for Research, 84-85, Brüssel, Luxemburg.

De Ketelaere, D., Hötzl, H., Neukum, Ch., Cività, M. \& G. Sappa, 2004: Hazard Analysis and Mapping. In: Zwahlen, F. (ed.), COST Action 620. Vulnerability and Risk Mapping for the Protection of Carbonate (Karstic) Aquifers. Final report COST Action 620.European Commission, Directorate-General for Research, 106-107, Brüssel, Luxemburg.

DoELG/EPA/GSI, 1999: Groundwater protection schemes.- Department of Environment and Local Government, Environmental Protection Agency and Geological Survey of Ireland, 24 pp., Dublin.
Ford, D.C. \& P.W. Williams, 2007: Karst hydrogeology and geomorphology.- John Willey \& Sons, Ltd, 562 pp., London.

Goldscheider, N., 2005: Karst groundwater vulnerability mapping - application of a new method in the Swabian Alb, Germany.- Hydrogeology Journal 13, 555-564.

Goldscheider, N., Hötzl, H., Fries, W. \& P. Jordan, 2001: Validation of a vulnerability map (EPIK) with tracer tests.- $7^{\text {th }}$ Conference on Limestone Hydrology and Fissured Media, Besançon $20^{\text {th }}-22^{\text {nd }}$ September 2001, Sci. Tech. Envir., Mém. H . S. n 13, 167-170.

Göppert, N. \& N. Goldscheider, 2007: Solute and colloid transport in karst conduits under low and high flow conditions.- Ground Water, published online (DOI: 10.1111/j.1745-6584.2007.00373.x).

Janža, M. \& J. Prestor, 2002: Ocena naravne ranljivosti vodonosnika v zaledju izvira Rižane po metodi SINTACS.- Geologija, 45/2, 401-406, Ljubljana.

Krivic, P., Juren, A., Bizjak, M. \& B. Ravnikar, 1987: Hidrogeološke raziskave zaledja Zgornje Pivke, IV. faza.- Geološki zavod Ljubljana, TOZD-I geologija, geotehnika, geofizika, 21 pp., Ljubljana.

Petrič, M. \& S. Šebela, 2004: Vulnerability mapping in the recharge area of the Korentan spring, Slovenia.Acta Carsologica, 33/2, 151-168, Ljubljana.

Ravbar, N. \& G. Kovačič, 2006: Karst water management in Slovenia in the frame of vulnerability mapping.Acta Carsologica, 35/2, 73-82, Ljubljana.

Ravbar, N. \& N. Goldscheider, 2006: Integrating temporal hydrologic variations into karst groundwater vulnerability mapping - examples from Slovenia.$8^{\text {th }}$ Conference on Limestone Hydrogeology, 229233, Neuchâtel.

Ravbar, N., 2007: The protection of karst waters : a comprehensive Slovene approach to vulnerability and contamination risk mapping.- ZRC Publishing, 254 pp., Ljubljana. 
Šikić, D. \& M. Pleničar, 1975: Osnovna geološka karta Jugoslavije. Tolmač za list Ilirska Bistrica.- Zvezni geološki zavod Beograd, 51 pp., Beograd.

Vías, J.M., Andreo, B., Perles, J.M., Carrasco, F. \& I. Vadillo, 2006: Proposed method for groundwater vulnerability mapping in carbonate (karstic) aquifers: the COP method. Application in two pilot sites in Southern Spain.- Hydrogeology Journal 14, 6, 912925.
Zwahlen, F., 2004: Vulnerability and Risk Mapping for the Protection of Carbonate (Karstic) Aquifers. Final report COST action 620.- European Commission, Directorate-General for Research, 297 pp., Brüssel, Luxemburg. 
